\title{
KORELASI MASA LEMAK DAN LEMAK VISERAL DENGAN KADAR LEPTIN SERUM PADA REMAJA OVERWEIGHT DAN OBESITAS
}

\author{
Rita Halim, Raihanah Suzan \\ ${ }^{1}$ Bagian Gizi Fakultas Kedokteran dan Ilmu Kesehatan Universitas Jambi \\ Email : Ritahalim fkik@unja.ac.id
}

\begin{abstract}
Background:The prevalence of adolescent obesity (15-18 years) in Indonesia continues to increase. The results of basic health research in 2013 showed the prevalence of adolescent obesity from 1.4\% in 2010 increase to $7.3 \%$ in 2013. The condition of obesity will affect leptin secretion which plays a role in influencing food intake by controlling appetite in the hypothalamus and brain stem. Objective: This study aims to determine the description, differences, and correlations of the fat mass, visceral fat, and serum leptin levels in the group of adolescents who are overweight and obese. Design: This study was conducted by analytic survey method with cross sectional approachment. The sample consisted of 60 people aged above 18 years state as students of the Faculty of Medicine and Health Sciences Jambi University who were overweight and obese. Analyze data from the examination of fat mass, visceral fat, and serum leptin using the Pearson Correlation test and for the characteristics of FKIK Unja students aged above 18 years with $B M I \geq 23$ will be analyze distributively. Results: The analysis showed significant results $p=0.000$ and a high correlation of $r=0.719$ between fat mass with leptin levels where the fat mass is directly proportional to leptin levels. The analysis showed that the results were not significant with $p=0.338$ and did not correlate $r=-0.126$ between visceral fat and leptin levels. Conclusions: From this study obtained a body composition profile, leptin level profile and food intake data in overweight and obese adolescents, which will be used as initial screening to make lifestyle modifications and healthy behavior in overweight and obese adolescents so that in the future they will not be a risk factor for metabolic syndrome
\end{abstract}

KEY WORDS: Obesity; Overweight; Fat mass; Visceral fat; Leptin

\begin{abstract}
ABSTRAK
Latar belakang: Prevalensi obesitas remaja di Indonesia terus meningkat. Hal ini dapat berdampak buruk terhadap kesehatan karena obesitas berkaitan dengan noncommunicable diseases (penyakit-penyakit tidak menular). Keadaan obesitas yang ditandai dengan meningkatnya massa lemak dan lemak viseral akan mempengaruhi sekresi leptin dan menyebabkan terjadi resistensi leptin, dimana kondisi hiperleptinemia pada obesitas menjadi faktor risiko independen terhadap penyakit kardiovaskuler.

Tujuan: Penelitian ini bertujuan untuk mengetahui korelasi masa lemak dan lemak viseral dengan kadar leptin pada remaja yang mengalami overweight dan obesitas

Metode: Penelitian ini dilakukan dengan metode survey analitik dengan pendekatan cross sectional. Sampel berjumlah 60 orang remaja overweight dan obesitas dengan usia 17- 25 Analisa data hasil pemeriksaan massa lemak, lemak viseral, dan leptin serum menggunakan uji Korelasi Pearson dan untuk karakteristik mahasiswa FKIK Unja usia $>18$ tahun dengan IMT $\geq 23$ akan dianalisis distributifnya. Hasil: Analisis menunjukkan hasil yang signifikan $p=0.000$ serta korelasi $r=0,719$ yang tinggi antara massa
\end{abstract}


lemak dengan kadar leptin dimana massa lemak berbanding lurus dengan kadar leptin. Analisis menunjukkan hasil yang tidak signifikan dengan $p=0.338$ serta tidak berkorelasi $r=-0,126$ antara lemak viseral dengan kadar leptin. kesimpulan: Dari penelitian ini didapatkan profil komposisi tubuh, profil kadar leptin dan data asupan makanan pada remaja yang overweight dan obesitas, yang akan dijadikan skrining awal untuk melakukan modifikasi gaya hidup dan perilaku hidup sehat pada remaja overweight dan obesitas sehingga kedepan tidak menjadi faktor risiko terkena sindroma metabolik.

KATA KUNCI: Obesitas; Overweight; Masa lemak; Lemak viseral; Leptin

\section{PENDAHULUAN}

Obesitas adalah keadaan dimana terjadinya ketidaknormalan karakteristik status nutrisi yaitu berlebinnya akumulasi lemak pada jaringan subkutanesus dan atau jaringan lain karena hasil dari ketidakseimbangan energi. Hasil riset kesehatan dasar tahun 2013 menunjukan prevalensi obesitas usia remaja dari tahun 2010 sebesar 1,4\% naik menjadi 7,3\% tahun 2013. Hal ini dapat berdampak buruk terhadap kesehatan karena obesitas berkaitan dengan noncommunicable diseases (penyakit-penyakit tidak menular) seperti kanker, penyakit jantung, dan diabetes tipe $2{ }^{(1)}$.

Keadaan obesitas akan mempengaruhi sekresi leptin. Leptin berfungsi mengatur massa jaringan adiposa dan berat badan dengan menghambat asupan makanan dan merangsang pengeluaran energi. Leptin mempengaruhi asupan makanan dengan mengontrol nafsu makan di hipotalamus dan batang otak. Remaja obesitas mengalami peningkatan kadar leptin karena leptin akan meningkat saat simpanan lemak dalam tubuh meningkat. Kadar leptin yang berlebihan menyebabkan sensitivitas otak terhadap leptin berkurang, sehingga terjadi gangguan fungsi pengontrolan nafsu makan dan pengeluaran energi yang disebut resistensi leptin (2).

Resistensi leptin merupakan salah satu dasar patologi pada kejadian obesitas, dimana hiperleptinemia pada obesitas menjadi faktor risiko independen terhadap penyakit kardiovaskular. Fungsi utama leptin adalah menyediakan sinyal simpanan energi yang ada dalam tubuh pada sistem saraf pusat sehingga otak dapat melakukan penyesuaian yang dibutuhkan untuk menyeimbangkan asupan energi dan pengeluaran .Sebagai kontrol terhadap keseimbangan energi pada manusia, leptin merupakan hormone anti obesitas yang didasarkan pada hipotesis bahwa kadar leptin yang tinggi akan mencegah terjadinya obesitas, sayangnya hal ini tidak terjadi, sebagian besar individu obesitas memiliki kadar leptin yang tinggi, namun tidak merangsang hilangnya massa lemak yang diharapkan. Beberapa peneliti telah menemukan bahwa kadar leptin lebih tinggi pada orang yang obesitas dibanding orang dengan berat badan normal ${ }^{(3)}$.

Secara normal lemak yang berlebih akan disimpan dilapisan subkutan, namun karena mengalami gangguan atau kerusakan maka lemak terakumulasi dilapisan viseral Distribusi lemak pada tempat yang berbeda memiliki implikasi 
terhadap morbiditas. Lemak abdominal dan intraabdominal (lemak viseral) memiliki signifikansi yang lebih besar dibanding lemak yang terdistribusi pada extremitas bawah atau seluruh tubuh (massa lemak). Studi prospektif dengan menggunakan pengukuran antropometri mendapati bahwa obesitas viseral memiliki kaitan erat dengan hipertensi, diabetes dan penyakit kardiovaskuler ${ }^{(3)}$.

Obesitas dibedakan menjadi obesitas abdominal atau viseral dan obesitas periper atau non viseral yang membedakan keduanya adalah bahwa lemak viseral memiliki reseptor glukokortikoid dan androgen lebih banyak, metabolism yang lebih aktif, lebih sensitive terhadap lipolisis dan lebih resisten insulin. Viseral Adipose Tissue (VAT) memiliki kapasitas lebih besar menghasilkan Free Fatty Acid (FFA), meningkatkan glukosa dan lebih sensitive terhadap stimulasi adrenergic ${ }^{(3)}$.

\section{METODE}

Penelitian ini merupakan metode survey analitik dengan pendekatan cross sectional. Jumlah sampel minimal yang diperlukan sebesar 55 orang dengan perkiraan drop out $10 \%$ (5 orang), sehingga keseluruhan sampel menjadi 60 orang.

Kriteria inklusi pada penelitian ini adalah mahasiswa yang berusia $>18$ tahun, sehat (tidak menderita penyakit metabolik atau penyakit kronis lainnya), dan IMT $\geq 23$. Sedangkan untuk kriteria eksklusi penelitian yaitu sedang menjalani program diet jenis apapun, sedang menjalani pengobatan jangka panjang seperti penggunaan steroid dan obat-obat anti kolesterol, dan sedang mengkonsumsi suplemen makanan seperti omega 3.

Data asupan makanan yang meliputi asupan energi, karbohidrat, lemak, protein dan serat pada penelitian ini dinilai dengan menggunakan food record 1×24 jam. Data asupan makanan tersebut dianalisis dengan perangkat lunak nutrisurvey 2007. Pengukuran antropometri yang dilakukan meliputi pengukuran berat badan, tinggi badan dan lingkar perut. Sedangkan pengukuran komposisi tubuh dilakukan dengan menggunakan Bioelectrical Impedance Analysis (BIA) merek TANITA. Pengambilan darah untuk menilai kadar laptin dilakukan dengan bekerjasama dengan Laboratorium Prodia Cabang Jambi. Analisis data menggunakan program statistik komputer dengan uji Korelasi Pearson atau peringkat Spearman.

\section{HASIL}

Lemak viseral pada subjek penelitian memiliki rerata $8,40 \pm 7,00$ dengan persentase kategori normal pada laki-laki $(66,7 \%)$ dan perempuan $(100,0 \%)$ paling tinggi. Untuk massa lemak pada perempuan dan laki-laki dikategorikan menjadi underfat, normal, overfat, dan obesitas dengan persentase tertinggi $47,6 \%$ pada laki-laki dalam kategori obesitas serta perempuan juga dalam kategori obesitas $(64,1 \%)$. Pada penelitian ini massa otot rerata subjek yaitu $50,33 \pm 40,40$ dan rerata kadar leptin $26763,80 \pm 24720,50$. (Tabel 1) 
Tabel 1. Karakteristik subjek penelitian

\begin{tabular}{|c|c|c|c|}
\hline Karakteristik & Nilai* $^{*}$ & $\begin{array}{c}\text { Laki-Laki } \\
\mathrm{n}(\%)\end{array}$ & $\begin{array}{c}\text { Perempu } \\
\text { an } \\
\mathrm{n}(\%)\end{array}$ \\
\hline $\begin{array}{l}\text { Jenis } \\
\text { kelamin }\end{array}$ & & $21(35,0)$ & $39(65,0)$ \\
\hline Lingkar & $89,40 \pm$ & & \\
\hline perut & 88,00 & $14(66,7)$ & $28(71,8)$ \\
\hline $\begin{array}{l}\text { Normal } \\
\text { Tinggi }\end{array}$ & & $7(33,3)$ & $11(28,2)$ \\
\hline Lemak & $8,40 \pm 7,00$ & & \\
\hline viseral & & $14(66,7)$ & $39(100)$ \\
\hline $\begin{array}{l}\text { Normal } \\
\text { Lebih }\end{array}$ & & $7(33,3)$ & $0(0)$ \\
\hline Massa & $35,85 \pm$ & & \\
\hline lemak & 37,35 & $0(0)$ & $0(0)$ \\
\hline Underfat & & $2(9,5)$ & $0(0)$ \\
\hline Normal & & $9(42,9)$ & $14(35,9)$ \\
\hline $\begin{array}{l}\text { Overfat } \\
\text { Obesitas }\end{array}$ & & $10(47,6)$ & $25(64,1)$ \\
\hline Massa otot & $\begin{array}{c}50,33 \pm \\
40,40\end{array}$ & & \\
\hline Kadar leptin & $\begin{array}{c}26763,80 \pm \\
24720,50\end{array}$ & & \\
\hline
\end{tabular}

Rerata asupan energi subjek penelitian adalah 1145,0 \pm 975,35 kkal, sedangkan berdasarkan jenis kelamin rerata asupan energi pada laki-laki lebih tinggi yaitu sebesar 1353,90 $\pm 1204,90$ dibandingkan perempuan sebesar 1032,51 \pm 943,70 kkal. Asupan protein pada subjek penelitian ini sebagian besar 41,09 $\pm 36,35$ dimana rerata asupan protein perempuan lebih rendah dari laki-laki. Asupan Karbohidrat pada subjek penelitian ini rerata $56,42 \%$ dari asupan energi, dengan rerata asupan laki-laki lebih tinggi dari perempuan. Pada penelitian ini didapatkan asupan lemak yg cukup rendah dibandingkan dengan jumlah asupan lemak yang dianjurkan oleh Kemenkes $\mathrm{RI}$ yaitu rerata hanya $13.9 \%$ dari total kalor. (Tabel 2 )

Tabel 2. Sebaran data asupan makanan pada subjek penelitian

\begin{tabular}{|c|c|c|c|}
\hline \multirow[t]{2}{*}{ Variabel } & \multicolumn{3}{|c|}{ Hasil } \\
\hline & $\begin{array}{l}\text { Total } \\
(n=60)\end{array}$ & $\begin{array}{l}\text { Laki-laki } \\
(n=21)\end{array}$ & $\begin{array}{l}\text { Perempuan } \\
(n=39)\end{array}$ \\
\hline $\begin{array}{l}\text { Asupan energi } \\
(\mathrm{kkal})^{*}\end{array}$ & $\begin{array}{c}1145,0 \\
\pm \\
975,35\end{array}$ & $\begin{array}{c}1353,90 \pm \\
1204,90\end{array}$ & $\begin{array}{c}1032,51 \pm \\
943,70\end{array}$ \\
\hline $\begin{array}{l}\text { Asupan } \\
\text { protein }(\mathrm{g})^{*}\end{array}$ & $\begin{array}{c}41,09 \pm \\
36,35\end{array}$ & $\begin{array}{c}47,69 \pm \\
46,30\end{array}$ & $\begin{array}{c}37,28 \pm \\
34,35\end{array}$ \\
\hline $\begin{array}{l}\text { Asupan } \\
\text { protein (\% } \\
\text { kal)* }\end{array}$ & $\begin{array}{c}16,28 \pm \\
14,55\end{array}$ & $\begin{array}{c}18,60 \pm \\
14,00\end{array}$ & $\begin{array}{c}15,03 \pm \\
14,78\end{array}$ \\
\hline Asupan & 158,93 & $180,50 \pm$ & $147,32 \pm$ \\
\hline Karbohidrat & \pm & 161,10 & 128,00 \\
\hline$(g)^{*}$ & 139,70 & $59,50 \pm$ & $54,76 \pm$ \\
\hline $\begin{array}{l}\text { Asupan } \\
\text { Karbohidrat (\% } \\
\text { kal)* }\end{array}$ & $\begin{array}{c}56,42 \pm \\
54,19\end{array}$ & 59,19 & 53,15 \\
\hline $\begin{array}{l}\text { Asupan lemak } \\
(\mathrm{g})^{*}\end{array}$ & $\begin{array}{c}41,97 \pm \\
37,10\end{array}$ & $\begin{array}{c}43,26 \pm \\
37,30\end{array}$ & $\begin{array}{c}41,28 \pm \\
36,90\end{array}$ \\
\hline $\begin{array}{l}\text { Asupan lemak } \\
(\% \text { kal })^{*}\end{array}$ & $\begin{array}{c}14,53 \pm \\
13,90\end{array}$ & $\begin{array}{c}13,23 \pm \\
12,81\end{array}$ & $\begin{array}{c}15,22 \pm \\
15,22\end{array}$ \\
\hline PUFA & $10,35 \pm$ & $8,46 \pm 4,60$ & $11,10 \pm 7,20$ \\
\hline$(g)^{*}$ & 6,50 & $16,55 \pm$ & $13,72 \pm$ \\
\hline MUFA & $14,71 \pm$ & 13,90 & 12,50 \\
\hline$(g)^{*}$ & 13,20 & $15,07 \pm$ & $21,38 \pm$ \\
\hline SFA & $19,17 \pm$ & 8,60 & 12,20 \\
\hline$(g)^{*}$ & $\begin{array}{c}11,30 \\
172,32\end{array}$ & $\begin{array}{c}223,13 \pm \\
191,00\end{array}$ & $\begin{array}{c}144,96 \pm \\
94,80\end{array}$ \\
\hline $\begin{array}{l}\text { Kolestr } \\
\text { ol }(\mathrm{mg})^{*}\end{array}$ & $\pm 94,90$ & & \\
\hline Serat $(g)^{*}$ & $\begin{array}{c}5,79 \pm \\
4,85\end{array}$ & $6,60 \pm 6,70$ & $5,35 \pm 4,40$ \\
\hline
\end{tabular}

* Data disajikan dalam mean \pm SD atau median (minimal-maksimal) 
Hasil analisis uji korelasi pada penelitian ini menunjukan terdapat korelasi positif yang signifikan anatara massa lemak dengan kadar leptin, dengan kekuatan korelasi yg tinggi yaitu sebesar 0,719. Sedangkan lemak viseral dengan kadar leptin tidak ada korelasi. (tabel 3 )

Tabel 3. Korelasi Massa Lemak dan Lemak Viseral dengan Kadar Leptin

\begin{tabular}{lcc}
\hline & \multicolumn{2}{c}{ Kadar Leptin } \\
\cline { 2 - 3 } & \multicolumn{2}{c}{ Total $(\mathrm{n}=60)$} \\
\cline { 2 - 3 } & $\mathrm{r}$ & $p$ \\
\hline Massa Lemak & 0,719 & 0,000 \\
Lemak Viseral & $-0,126$ & 0,338
\end{tabular}

\section{PEMBAHASAN}

Lingkar perut dan lemak viseral pada subjek dalam penelitian ini termasuk dalam kategori normal baik laki-laki maupun perempuan. Hal ini tidak sejalan dengan penelitian yang dilakukan oleh Hsin-DC yaitu perempuan memiliki risiko lebih tinggi penyimpanan lemak sentral dan pada jarigan adiposa yang terlihat pada perempuan dengan berat badan berlebih. Meskipun begitu Hsin-DC juga menerangkan bahwa etnis/suku juga mempengaruhi dalam hal ini (4). Seperti dengan lingkar perut, rasio lingkar perut panggul juga menggambarkan akumulasi lemak dalam rongga perut. Hal itu juga menggambarkan adanya obesitas sentral/abdominal. Semakin besar perbandingan antara RLPP maka semakin besar lemak rongga perut ${ }^{(5)}$.

Pada penelitian ini subjek perempuan dan laki-laki memiliki kadar massa lemak yang tinggi, termasuk dalam kategori obesitas. Selaras dengan penelitian I wayan, frekuensi makan makanan cepat saji berhubungan positif dengan asupan kalori total dan meningkatkan massa lemak tubuh. Orang obesitas lebih banyak memilih makan di restoran cepat saji dibandingkan orang normal, namun hal ini tidak terjadi pada orang yang mengalami gangguan makan. Perubahan perekonomian keluarga akan meningkatkan kemampuan membeli makanan di luar rumah, sehingga hal ini mampu menjelaskan peningkatan prevalensi obesitas $\left.{ }^{6}\right)$. Hal ini juga didukung oleh penelitian Weni yang menjelaskan faktor penyebab obesitas pada remaja bersifat multifaktorial. Peningkatan konsumsi makanan cepat saji (fast food), rendahnya aktivitas fisik, faktor genetik, pengaruh iklan, faktor psikologis, status sosial ekonomi, program diet, usia, dan jenis kelamin merupakan faktor-faktor yang berkontribusi pada perubahan keseimbangan energi dan berujung pada kejadian obesitas ${ }^{(7,8)}$.

Kadar leptin dalam penelitian ini didapatkan rerata 26763,80 dari 60 total sampel yang diteliti. Beberapa peneliti telah menemukan bahwa kadar leptin lebih tinggi pada orang yang obesitas dibanding orang dengan berat badan normal. Kadar leptin yang bersirkulasi dalam darah orang normal diketahui sebesar 1-3 $\mathrm{ng} / \mathrm{mL}$, sedangkan kadar leptin yang bersirkulasi dalam darah penderita obesitas sebesar $100 \mathrm{ng} / \mathrm{mL}{ }^{(9)}$.

Massa otot dalam penelitian ini didapatkan rerata 50,33 dari 60 total sampel yang diteliti. Masa remaja merupakan masa pertumbuhan cepat dan terjadi perubahan signifikan pada komposisi tubuh yang mempengaruhi aktivitas fisik dan respon 
terhadap olahraga atau latihan. Terdapat peningkatan pada ukuran tulang dan massa otot serta terjadi perubahan pada ukuran dan distribusi dari penyimpanan lemak tubuh. Remaja memiliki kesegaran jasmani yang berbeda setelah masa pubertas. Tingkat kesegaran jasmani pada remaja perempuan cenderung lebih rendah dibandingkan laki- laki, hal ini terkait dengan perbedan kadar hemoglobin, komposisi tubuh dan tingkat aktivitas fisik (10).

Rerata asupan energi subjek penelitian adalah $1145,0 \pm 975,35 \mathrm{kkal}$, sedangkan berdasarkan jenis kelamin rerata asupan energi pada laki-laki lebih tinggi dibandingkan perempuan. Hal ini seleras dengan hasil penelitian yang dilakukan oleh Ulfah, rata-rata asupan energi makanan lebih tinggi pada laki-laki daripada perempuan. Konsumsi makanan dengan kepadatan energi tinggi (banyak mengandung lemak, gula dan kurang menggandung serat) secara berlebihan berkontribusi dalam peningkatan asupan energi total. Sedangkan konsumsi makanan dengan densitas energi rendah mampu menurunkan asupan energi total ${ }^{(11)}$.

Rerata asupan protein dan persentase asupan protein pada subjek penelitian perempuan lebih rendah dari lakilaki. Penelitian yang dilakukan oleh Weni menjelaskan bahwa asupan protein yang lebih pada kelompok nonobesitas ditemukan lebih tinggi dibandingkan kelompok obesitas. Hasil analisis menunjukkan asupan protein bukan merupakan faktor risiko terjadinya obesitas. Asupan protein merupakan faktor protektif, disini asupan protein digunakan sebagai energi. Hal ini disebabkan asupan lemak dan karbohidrat tidak cukup sehingga memecah protein. Apabila tubuh kekurangan zat energi, fungsi protein untuk menghasilkan energi atau untuk membentuk glukosa akan didahulukan. Bila glukosa atau asam lemak didalam tubuh terbatas, sel terpaksa menggunakan protein untuk membentuk glukosa dan energi (7). Hal ini selaras dengan penelitian yang didapatkan yaitu meski laki-laki memiliki rerata asupan protein yang tinggi daripada perempuan, tetapi persentase obesitas laki-laki tidak lebih tinggi dibandingkan dengan perempuan.

Rerata asupan karbohidrat dan persentase asupan karbohidrat pada lakilaki lebih tinggi daripada perempuan pada penelitian ini. Hal ini bertolakbelakang dengan penelitian Weni yaitu asupan karbohidrat berlebih pada kelompok obesitas ditemukan lebih tinggi dibandingkan kelompok tidak obesitas (7). Usia remaja rentan akan risiko obesitas karena pada usia ini remaja mengalami penurunan aktivitas fisik, peningkatan konsumsi tinggi lemak, dan tinggi karbohidrat (12). Banyak faktor yang mempengaruhi obesitas yaitu salah satunya merupakan aktivitas fisik, laki-laki cenderung untuk memiliki aktivitas yang lebih tinggi daripada perempuan sehingga dapat menjadi faktor pendukung ditemukannya rerata asupan karbohidrat yang lebih tinggi pada laki-laki meskipun perempuan yang cenderung mengalami obesitas.

Laki-laki memiliki kadar asupan lemak yang lebih tinggi daripada perempuan tetapi untuk persentase kalori pada asupan 
lemak perempuan memiliki rerata yang lebih tinggi dibandingkan laki-laki. Hal ini selaras dengan penelitian Camelia yang menjelaskan bahwa pada anak perempuan yang obesitas cenderung memiliki persentase lemak tubuh dan leptin yang lebih tinggi dibandingkan laki-laki (1). Pada penelitian ini kadar PUFA dan SFA lebih tinggi pada perempuan dan kadar MUFA serta kolestrol yang lebih tinggi pada lakilaki. Hal ini juga selaras dengan penelitian Camelia, anak yang mengalami obesitas menunjukkan kadar leptin, kolestrol total, kolestrol LDL, trigliserida dan kadar HDL kolestrol yang rendah (1).

Pada penelitian ini rerata serat yang dikonsumsi oleh laki-laki lebih tinggi daripada perempuan. Asupan serat yang rendah dapat menyebabkan gizi lebih, karena kecenderungan mengkonsumsi makanan tinggi lemak yang lebih mudah dicerna dibandingkan serat. Seseorang dengan pola makan mengandung serat yang sesuai kebutuhan, jarang ditemui mengalami gizi lebih. Remaja yang gizi lebih membutuhkan lebih banyak makanan yang mengandung serat terutama dari sayur. Serat juga menimbulkan efek kenyang yang lebih lama sehingga tidak cepat timbul lapar. Asupan tinggi serat tidak akan menyumbang energi lebih sehingga dapat membantu mengontrol berat badan. ${ }^{(13)}$.

Pada penelitian ini didapatkan hasil yang signifikan $(p=0.000)$ antara massa lemak dengan kadar leptin dimana massa lemak berbanding lurus dengan kadar leptin dengan korelasi yang tinggi( $r=0,719$ ) Berdasarkan penelitian yang dilakukan oleh Camelia, kadar leptin berkolerasi dengan persentase jaringan lemak. Pada anak obesitas kadar leptin secara signifikan lebih tinggi dibandingan dengan anak kategori normal. Kadar leptin pada anak perempuan obesitas lebih tinggi daripada anak laki-laki dengan obesitas jika dibandingkan dengan anak kategori berat badan normal dimana tidak terdapat perbedaan jenis kelamin dalam kategori ini ${ }^{(1)}$.Hal ini juga didukung dengan penelitian Martin yaitu kadar leptin serum telah ditemukan positif berhubungan dengan IMT, lingkar pinggang, massa lemak, insulin, dan HOMA-IR pada populasi di Afrika (14). Sebagian besar individu dengan obesitas mengalami hiperleptinemik dan resistensi leptin yang secara langsung berhubungan dengan proses obesitas. Resistensi leptin menyebabkan meningkatnya akumulasi trigliserida pada jaringan adiposa, otot, hati, dan pankreas (14). Secara umum, terdapat tiga keadaan yang melatarbelakangi obesitas, yaitu keadaan ketika tubuh gagal memproduksi leptin saat terjadi akumulasi lemak, keadaan kedua yaitu ketika jaringan adiposa mensekresikan leptin dalam jumlah yang rendah, sehingga massa lemak akan terus bertambah hingga kadar leptin yang normal tercapai. Peningkatan massa lemak ini akan mengarah pada obesitas. Keadaan ketiga, obesitas terjadi karena leptin menjadi insensitif secara relatif atau absolut pada sisi aksinya, resistensi ini terjadi karena ada peningkatan leptin dalam sirkulasi darah ${ }^{(4)}$.

Leptin berfungsi sebagai kontrol terhadap keseimbangan energi pada manusia, leptin merupakan hormone anti obesitas yang didasarkan pada hipotesis bahwa kadar leptin yang tinggi akan 
mencegah terjadinya obesitas. Sayangnya hal ini tidak terjadi, sebagian besar individu obesitas memiliki kadar leptin yang tinggi, namun tidak merangsang hilangnya massa lemak yang diharapkan ${ }^{(9)}$.

Pada penelitian ini didapatkan hasil yang tidak signifikan $(p=0.338)$ antara lemak viseral dengan kadar leptin. Hasil penelitian ini selaras dengan penelitian yang dilakukan oleh Yulina dimana tidak ada perbedaan yang nyata antara rerata kadar leptin pada kelompok obesitas viseral dengan non viseral. Hal ini disebabkan karena leptin lebih terkait dengan akumulasi lemak ditubuh dan bukan pada region dimana lemak berada. Obesitas viseral tidak semata-semata menggambarkan kandungan lemak dalam tubuh tetapi lebih menunjukkan regio dari lemak berada. Leptin adalah hormone yang disekresi oleh sel lemak dengan proporsi terhadap penyimpanan lemak tubuh sehingga konsentrasi leptin dalam sirkulasi bersifat parallel terhadap IMT, persentase lemak tubuh dan berat lemak tubuh total (3).

\section{KESIMPULAN DAN SARAN}

Pada penelitian ini didapatkan korelasi positif yang bermakna antara massa lemak dengan kadar leptin, sedangkan lemak viseral tidak berkorelasi dengan kadar leptin. Hal ini disebabkan karena kadar leptin lebih terkait dengan akumulasi lemak didalam tubuh bukan pada regio dimana lemak berada. Saran untuk penelitian berikutnya yaitu pemeriksaan biomarker yang lebih spesifik lagi untuk penanda sindroma metabolik pada remaja overweight dan obesitas.

\section{DAFTAR PUSTAKA}

1. Alkhzouz C, Lazea C, Nascu I, Cotlet A. Correlation Between Body Mass Index, Body Fat Proportion And Leptin Level In Obese Children. Jurnalul Pediatrului. 2015;Xviii:4.

2. Subarjati A, Nuryanto. Hubungan Indeks Massa Tubuh Dengan Kadar Leptin Dan Adiponektin. Journal Of Nutrition College. 2015;428-34.

3. Hastuty Yd, Siregar Y, Silaban R. Analisis Kadar Leptin Pada Obesitas Viseral Dan Non Viseral. Fakultas Kedokteran Universitas Sumatera Utara. 2011;9.

4. Chen H-D, Wu D-A, Hou J-S, Subeq Y-M, Li J-C, Hsu B-G. Positive Correlation Of Serum Leptin Levels With Obesity And Metabolic Syndrome In Patients With Type 2 Diabetes Mellitus. Divisions Of Metabolism And Endocrinology Tzu Chi University, Hualien, Taiwan Int J Clin Exp Pathol. 2017;4852-9.

5. Rahmadinia L. Hubungan Lingkar Perut Dan Rasio Lingkar Perut Panggul Dengan Kadar Gula Darah Puasa Pada Anggota Tni Kodim 0735 Surakarta. [Program Studi Pendidikan Dokter Fakultas Kedokteran]: Muhammadiyah Surakarta; 2018.

6. Ida A 7. I Wayan G. Terapi Diet Pada Obesitas. [Denpasar]: Udayana; 2015.

7. Kurdanti W, Suryani I, Syamsiatun Nh, Siwi Lp, Adityanti Mm, Mustikaningsih D, Dkk. FaktorFaktor Yang Mempengaruhi Kejadian Obesitas Pada Remaja. Jurnal Gizi Klinik Indonesia. 30 April 2015;11(4):179.

8. Agustina W, Jus'at I, Mulyani Ey, Kuswari M. Asupan Zat Gizi Makro Dan Serat Menurut Status Gizi Anak Usia 6-12 Tahun Di Pulau Sulawesi. 2015;10:8.

9. Cahyaningrum A. Leptin Sebagai Indikator Obesitas. 2015;9(1):1364-71.

10. Murbawani Ea. Hubungan Persen Lemak Tubuh Dan Aktivitas Fisik Dengan Tingkat Kesegaran Jasmani Remaja Putri. Journal Of Nutrition And Health. 2017;5(2).

11. Dewi Up, Dieny Ff. Hubungan Antara Densitas Energi Dan Kualitas Diet Dengan Indeks Massa Tubuh (Imt) Pada Remaja. Journal Of Nutrition College. 2013;2(4):447-57.

12. Adriani M Wb. Peranan Gizi Dalam Siklus Kehidupan. Jakarta: Kencana 
Prenada Media Group; 2012. 245-278 HIm. (2).

13. Setyawati Vav, Rimawati E. Pola Konsumsi Fast Food Dan Serat Sebagai Faktor Gizi Lebih Pada Remaja. Ujph. 31 Juli 2016;5(3):275.

14. Myers Mg, Leibel RI, Seeley Rj, Schwartz Mw. Obesity And Leptin Resistance: Distinguishing Cause From Effect. Trends In Endocrinology \& Metabolism. November 2010;21(11):643-51 